\title{
Demographic Influence on Muslim Flood Victim Wellbeing in Flood Prone Districts in Malaysia
}

\author{
Husni Mohd Radzi, Sapora Sipon, Khatijah Othman, Nik Nadian Nisa Nik Nazli, and Zulkifli Abd \\ Ghani
}

\begin{abstract}
This study compares the Muslim flood victims' wellbeing and their practices of Muslim religious personality as coping strategies in dealing with disaster stress in four different districts in Malaysia. The studies involved a survey conducted in two separate studies involving four different districts in Peninsular Malaysia. The districts chosen were Kuala Terengganu and Dengkil for study one; while the other two districts were Besut in Terengganu and Salak Tinggi, in Sepang Selangor for the second study. A total of 200 flood victims had participated in this study with majority were from Malay origin and Muslim in faith. Both studies have gathered 100 sample for each studies. The participants were randomly selected in the flood relief center to answer the questionnaires given. The result was analyzed and compared descriptively. Lower education level has serious influence towards sample understanding of the item used. It also influenced the respondent job and income which have shaped the non-significant result of all the inventories used in these two studies.
\end{abstract}

Index Terms-Demographic characteristic, education level, Islamic teaching knowledge, young adult respondents, flood disaster coping mechanism.

\section{INTRODUCTION}

This paper intended to compare the findings of two surveys carried out in the early 2013. The preliminary studies were done by two students of Universiti Sains Islam Malaysia in Nilai named, Idarayanie Mohd Zawawie and Suhana Talib. The objective of this study was to identify the level of stress among flood victims and the religious coping skill used. Besides, this study also investigated the relationship between Muslim religious personalities and the relationship in dealing with disaster stress. Not only have the two studies gathered sample from similar areas, it also adopted similar inventories. Thus, the study would compare the results between two studies that took place in 2012. The first study took place in Kuala Terengganu and Dengkil with a total sample of 100 flood victims. This is referred to as study one. The second study was conducted in Besut, Terengganu and Salak Tinggi Selangor with also 100 respondents $(N=100)$. This is referred as study two from now

Manuscript received February 15, 2014; revised April 27, 2014. This work was supported in part by the Ministry of Higher Education of Malaysia under Grant LRGS USIM/LRGS (UUM)/FKP/ULUM/34/50112. Demographic Influence on Muslim Flood Victim Wellbeing in Flood Prone Districts in Malaysia.

The authors are with the Faculty of Leadership and Management, Universiti Sains Islam Malaysia (USIM) (e-mail: husni@uniten.edu.my, sapora@usim.edu.my, khatijah@usim.edu.my,nadian_nisa13@yahoo.com, drzulkip@usim.edu.my). on. The data that will be compared were taken from Muslim Religious Personality Inventory (MRPI) [1]

Adopting a religious behavior and thinking to manage stress and trauma has been performed by many people in various situations. [2] Pargament et al. found that religious coping efforts involving the belief in a just and loving God, the experience of God as a supportive partner, involvement in religious rituals, and the search for spiritual and personal support were significantly related to better outcomes, such as recent mental health status and spiritual growth. [3] Whilst, negative spiritual coping refers to questions, confusion, or anger toward God [4]. Non-spiritual coping refers to other behaviors observed such as in the wake of $9 / 11$, people displaying the flag. Positive spiritual outcomes include feeling closer to God, one's faith on community, and one's significant to others [5].

In this study, the results to be compared were the overall psychological wellbeing and their practice of Muslim religious personality among Muslim flood victim in dealing with flood disaster stress. This study involved flood Anxiety and fear as a basic human emotion that can be seen as normal internal or external reactions in dealing with stressor that was deemed crucial for the survival [6].

Anxiety can be explained as the feeling of lack of control related to future of things that are uncertain, which may lead to negative results [7]. According to Diagnostic and Statistical Manual of Mental Illness (DSM IV), anxiety is a feeling that is illogical but the person who experienced it felt unable to control their worries [8]. When the feelings of illogical fear become so overwhelmed, it may escalate which leads to anxiety disorder [9].

In Islamic point of view, anxiety is considered as spiritual disease which develops from unhealthy spiritual beliefs deep-rooted in the human heart [10]. Al-Ghazali, a prominent Muslim figure in Islamic spirituality has characterized anxiety as 'fear towards certain things which leads to restlessness and frustrated feelings' [11]. Fear towards inevitable environmental factors such as old age, poverty, losing status quo and job can sometimes lead a person to experience breakdown and lose their self-esteem. The pressure of dealing with life issues such as divorce, death of loved ones, health and financial problems can be very stressful that it eventually leads to anxiety [12]. It is common that many people cope with their anxiety by consumption of alcohol and other substances or recreational drugs which quickly lead them into severe problem which may have long term effects, such as addiction. The problem may then affect their functioning and relationship with family, friends and their work at the workplace. 
The Islamic faith believes that anxiety is developed within a person's spiritual and psychological outlooks, which includes the weakness in asserting control through one's heart and mind, faith or believe system attached with the influence of worldly or narcissistic desires [13], [14]. Being in this state has opened the door to Satan's domination over the human spirits as a result of diminishing religious beliefs and insufficient submissions to Allah SWT. [15]. Therefore in the Islamic point of view, a person who succumbed to worldly temptations or narcissistic desires indicates lacking in self-control and poor attachment to the spiritual aspects or religious practices and faith.

\section{ANXIETY EFFECT}

\section{A. The Effects of Anxiety}

In dealing with the demands of life, anxiety may interferes with daily functioning of an individual by reducing focus in thinking, causing inability to sleep and eat, unstable emotions and fatigue [7]. Psychologically anxious person would feel constant worries, feeling upset and fearful without any real reason to the extent of staring blankly, crying or losing their self-esteem [10]. Person afflicted with anxiety and other related mental health problem may exhibit decreased perception of their own self-worth [16]. This can lead to another serious psychological disturbance which is depression [17]. Depression is serious psychological disturbances that have caused millions of suicides cases every year [18].

\section{RELIGIOUS COPING}

Religious ritual such as prayers, meditation and reading sacred text are reported to lower anxiety and depression and reduction in the consequences of stressful life event [19]. The use of spirituality and religiosity practice in the form of adaptive manner can be helpful to individual who have series of psychological distress [20]. Thus, person who utilizes any religious act such as praying or reading sacred text to address the anxiety is known as religious coping [21]. Krauss [22] posited that Islam is a religion that denotes a comprehensive religious way of life. Ad-Din in Islam implies the sanctification of all daily living into worshipful acts that unify life consistent with 'tawhidic' principles (oneness of Allah) of the divine unity. Al-Quran 4: 125.

"Who is better in religion than he who surrendereth his purpose to Allah while doing good (to men) and followeth the tradition of Abraham, the upright? Allah (Himself) chose Abraham for friend. (125)."

The Islamic teaching and practice or Ad-Din should be able to build Muslim in maintaining this dynamic sphere and moving forward. An ideal Muslim is progressing in their quest of self-purification, self-perspective through worship, ongoing acquisition of knowledge and performing selfless act. Therefore, this study was designed to distinguish the level of anxiety that can be altered or influenced by a person's understanding and application of Islamic teaching and worldview.

\section{MethodS}

\section{A. Sample}

This study used a survey method. Sets of questionnaires were used to obtain the result from these two studies. The questionnaires were designed to look into the effects on stress, self-esteem and spiritual coping strategies of flood victims. Permission was first obtained from the authority of the four targeted flood area. After receiving approval, the researcher would ask for the willingness of the respondents to participate in the survey process. Brief explanations were given to all the respondents regarding the item and the procedures of attempting the questionnaires. The respondents were given approximately 20- 30 minutes to complete the questionnaires. During the process, respondent were allowed to ask question related to the survey question distributed. The first study was conducted in two different places which are Kuala Terengganu, Terengganu and Dengkil, Selangor while the second study was conducted at two places namely Salak Tinggi, Sepang and Besut, Terengganu.

\section{B. Instruments}

The participants had to respond to two set of inventories. The first survey used was 'Brief Religious Coping' (BRCOPE) by Pargament [23]. The BRCOPE objective was to gauge the religious coping used by respondents in managing anxiety. The second instrument used was 'Depression Anxiety and Stress Scale' (DASS) by Lovibond \& Lovibond [24] meant to measure the severity of depression, anxiety and stress that respondents have experienced in the past weeks. For this study, only anxiety will be given attention to. The BRCOPE emphasizes on sample's coping behavior during anxious situations. The response showed indicates the type of coping behaviors that are frequently used or most effectively used in managing anxiety. Using BRCOPE alone is not sufficient in measuring the severity of the anxiety level. Thus, DASS is used to determine the level of anxiety experienced with the coping behavior used by the study sample.

The population for this study was selected from flood victims at Kuala Terengganu, and Besut in Terengganu and the other areas are Salak Tinggi and Dengkil, Selangor. The total number of sample used was $200(\mathrm{~N}=200)$ for both studies where the respondents were randomly selected. Among these respondents, 36 were male and 64 were female from the first study and 51 males and 49 females from the second study. The average age group was between 31 years old to 40 .

The first study used three sets of questionnaires which consist of Muslim Religiosity Personality Inventory [1], Disaster Stress Scale (DSS) and Coping Skill (CS). Muslim Religiosity Personality Inventory (MRPI) consists of 12 items which identify the personality of Muslim Religiosity. Disaster Stress Scale (DSS) also has 12 items which identify the level of stress when faced with disaster. In Coping Skill (CS) questionnaire, there are 20 items which measure the ways to manage stress. All three inventories measured the respond using Likert's type scale. Data gathered were analysed using Statistical Package for Social Science (SPSS). Descriptive statistic was generated. 
The second study employs MRPI and Self-Esteem Inventory (SEI). SEI is an inventory meant to measure the level of self-esteem of a person in the time of difficulties or disaster. It is also a Likert's type scale. For the purpose of this paper alone, only the result of MRPI are compared and analyzed between the two studies.

\section{RESUlts}

\section{A. Demographic Data}

The respondents' races in this research are divided into 4 categories. They are Malay, Chinese, Indian and others. The respondents' groups of age in this research consist of 5 groups. Group one is 20 years old and below, group two is between 21 years old to 30 years old, group three is between 31 years old to 40 years old, group four is between 41 years old to 50 years old and group five is 51 years old and above. The educational level of respondent in this research consists of five groups. Group one is lower secondary, followed by Diploma, Degree, Post graduates and others. There are four groups of incomes of the respondents. Group one is unemployed, group two's income range is between RM1000-RM2500, followed by RM2501-RM5000 and RM5001-RM7500 for group four. The respondents' occupations in this research consist of five types of occupations. First is unemployed, second is private sectors, followed by government sectors, business and others. The data can be summarized as follows:

TABLE I: DEMOGRAPHIC DATA OF THE TwO STUDIES COMPARED

\begin{tabular}{l|cc}
\hline Demographic data & Study 1 $(N=100)$ & Study 2 $(N=100)$ \\
\hline Race (majority) & 74 & 96 \\
Age (21 -30 years & 44 & 49 \\
old) & 42 & 49 \\
$\begin{array}{l}\text { Education (Lower } \\
\text { secondary) }\end{array}$ & 53 & 61 \\
Employment & (government sector) & (unemployed) \\
Income & RM 1k-RM 2500 & No income \\
\hline
\end{tabular}

Descriptive analysis was performed towards both studies research findings. Looking at the sample population, the majority of the flood victims were from Malay origins and Muslim in faith. The average age group for respondents fell in the second age categories ranging from 21 to 30 years old. This group age indicated that a younger group of adult that may have just finish their first degree or still in their tertiary level. In this study however, the majority of the sample only have secondary level education. The samples in both studies stated that they were in the lower income group (RM 1000 to RM 2500) or no income at all. The data also indicated the majority of the sample working in the government sector, but judging by the income range the post that the majority of respondent held were clerical and below.

\section{B. Age Group}

The studies observed a majority of young generation being the victim of flood disasters. At this age, people usually occupy themselves with study, play around or just starting to live independently without their parental support. These young adults may have the tendency to not taking matters seriously and likely do not involve themselves in serious working activities. Answering sets of serious question that need concentration and understanding may not be attractive or appealing to them. The respondents may also feel that they should spend their time proactively improving their current condition rather than wasting time answering set of question that did not help their physical condition. Being young also do contribute to some impact in the context of religiousness. Since the research sample mainly from the age of 20 until 31 they may not practice the Islamic teaching or personality as much as the older people. The uncomfortable and chaotic environment in the relief center may also distract their attention and focus in responding to the inventories given.

\section{Religious and Education Level}

Education level of the research sample may have great influences on the overall outcome of these two studies. Education has been widely perceived as one of the most important socio-economic determinants of health and mortality [25]. This is similar to previous study where education level does predict the level of practice and application of the knowledge in daily life [26]. The study observed how much the nurses and social workers applied ethics and moral standard base on their level of education. As for the flood victim, having low qualification makes answering sets of complex questionnaire using formal sentence and word not so suitable. The respondents may have difficulties in understanding the meaning of the item being asked. [27] Csikai \& Raymer also mentioned that having lower education also lead to the thinking that there are under qualified to give suggestion and opinions. Similar study also reported to observed respondents who undergone ethical and moral education have better world view, values, tools and skills to deal with ethical and moral issues in their daily life [27], [28]. Another effect of low education is the hesitation to try, participate or engage in a certain unfamiliar service. Since the flood victim are also low in education level, lacking knowledge in Islamic teaching also may have cause the research sample not applying the religious coping techniques as much as being predicted. Thus, the result is not significant in Muslim religiosity and personality context as being analyzed through MRPI.

\section{Employment and Income Level}

Education does effect respondents' employment. A social study conducted previously have demonstrated that education level have a significant impact on a person lifestyle, health behavior, problem solving abilities, social relations, self-esteem, stress management, income and occupation [29] [30]. Being young and having no tertiary qualification, the sample mainly work with a minimum or low income job. As the demographic data showed, the no income and unemployed respondents are larger in number compared to the employed samples. Living with a minimum wage between below RM 1000 to RM 2500, the respondents may not have many valuable or expansive material things in their possession. This may also indicates that they have already live in a hard condition even before being hit by the flood. 
Thus, the sense of losing valuable material things may not be so intense which explained the non-significant result for DSS, CS and SEI.

The study also gathered its data using one method only which is survey method. Future researcher may need to combine with interview and observation as to gain more in depth and thorough understanding about the concept and application of god consciousness and religious coping among Muslim people in Malaysia and maybe other Muslim countries as well.

\section{DISCUSSION AND SUGGESTIONS}

\section{A. Attaining God Consciousness as Religious Coping}

In Islam, god consciousness is known as 'taqwa' from the Arabic word of 'Waqa yaqi, ittaqa yattaqi' which mean to shield and to protect one self. 'Taqwa' is a process that involves consistency, commitment and responsibility to be fulfilled by a Muslim [31]. Stress and anxiety are viewed by god fearing people as test and opportunity to improve and become better Muslims. 'Taqwa' promotes constancy in god's consciousness and fearing in every Muslim's mind. As a result, Muslim will be careful in guarding their mind, thought, behavior and tongue from committing the forbidden (haram) and disliked (makruh) behavior that can weaken and pollute the heart. By having a strong faith and fear of Allah, Muslim will be blessed and protected by God from disease of the heart such as anxiety, stress and depression.

'Taqwa' plays a large role in Islamic morals and ethics because it is truly what makes people ethically aware of their actions in relation to God. 'Taqwa' gives people a reason to do the right thing. The awareness of God's power makes people want to please him, making 'taqwa' a moral and ethical base for their actions. Because of this construct, 'taqwa' is one of the "ideal ethical values" of the religion of Islam [32]. Thus, 'taqwa' is an effective religious coping strategy for Muslim to manage stress and anxiety.

\section{CONCLUSION}

This paper has discussed how demographic characteristic of the respondents have significant influence on the entire research findings. Level of education has greatly influenced the type of employment, income and level of Islamic knowledge of the flood victim. Another variable which is age group may have influence the response and coping strategy used by the flood victim who indicates moderate or low Islamic coping skills used throughout the flood disaster occurrence. Although the inventories used did not give much information that originally intended, the demographic data has given various crucial and important information about flood victims' wellbeing. For future study, the researcher suggests that this study will conduct using qualitative and quantitative survey. Qualitative survey such as interviewing flood maybe more accurate and less stressful to the victim and the data gathered would also be more in-depth and meaningful. Survey inventories may be given on later date after the flood victims have settle down in their living environment. Thus careful planning and exact timing need to be carefully considered. Observation study may also help in gathering data regarding the application of Islamic practice of the flood victim during their time in the relief center. By recording the behavioral occurrence of Islamic practice such as praying, it can provide more inputs about religious coping strategies used.

The research finding also supported by previous research [33] has indicated about the effect of religiosity as protective elements of lifetime religious behavior that enhanced the treatment along with the common treatment of psychotherapy, pharmacology or both. The empirical evidence indicates that religious behaviors are linked to reduced risks and relapse as well as improved post treatment outcome. The overall improvement of clinician-rated global functioning are also reported as a result of greater religious practices.

Hence, on the other hand, the Muslim flood victims' wellbeing is protected from the feeling of depressions and anxieties due to their staunch believer in the faith and spiritual religious practices. Islam emphasized on maintaining the balance between the human body and human soul to achieve total wellbeing of life. With both the spiritual (tawakkal/strong faith) and physical strengths, the Muslim flood victims are able to handle the situation better and prevent themselves from the deterioration of psychological disease.

\section{REFERENCES}

[1] F. Idris, S. E. Krauss, A.-L.Abdullah, and H. A. Hamzah, "The muslim religiosity-personality inventory (MRPI): Towards understanding differences in the Islamic religiosity among the Malaysian youth," Malaysia: Universiti Putra Malaysia.

[2] K. I. Pargament, D. S. Ensing, K. Falgout, H. Olsen, B. Reilly, K. V. Haltsma et al., "God help me: (I) Religious coping efforts and predictors of the outcomes to significant negative life events,' American Journal of Community Psychology, vol. 18, pp. 793-824, 1990.

[3] K. I. Pargament, B. W. Smith, H. G. Koenig, and L. Perez, "Patterns of positive and negative religious coping with major life stressors," Journal for the Scientific Study of Religion, vol. 37, pp. 710-724, 1998.

[4] K. I. Pargament, J. Kennell, W. Hathaway, N. Grevengoed, J. Newman, and W. Jones, "Religion and the problem solving process: Three styles of coping," Journal for the Scientific Studyof Religion, vol. 27, pp. 90-104, 1988.

[5] R. Boon. (June 2013). Anxiety. [Online]. Available: http://home.jprimus.com.au/boon/AnxietyPTSDetc.html

[6] G. H. Koenig, E. M. Mccullogh, and B. D. Larson. Handbook of Religion and Mental Health, Oxford University, 2001, pp. 1118-1120.

[7] D. H. Barlow and C. L. Lehman, "Advances in the psychosocial treatment of anxiety disorders. Implications for national health care," Archives of General Psychiatry, vol. 53, pp. 727-735, 1996.

[8] J. P Feighner and W. F. Boyer, "Serotonim-1A anxiolytics: An overview," Psychopathology, vol. 22, pp. 21-26, 1989.

[9] K. Rickels, K. Weisman, N. Norstad, M. Singer, D. Stoltz, A. Brown, and J. Danton. "Buspirone and diazepam in anxiety; A controlled study," Journal of Clinical Psychiatry, vol. 43, pp. 81-86, 1982.

[10] E. Thackery (Ed.), The Gale Encyclopedia of Mental Disorders, The Gale Group, Inc. 2003.

[11] T. D Borkovec, M. G. Newman, and L. G. Castonguay, "Cognitive-behavioral therapy disorder with integration from interpersonal and experiential therapies," The Journal of Life Long Learning in Psychiatry, vol. 11, no. 3, pp. 393, 2004.

[12] R. C. Durham, "Treatment of general anxiety disorder," Psychiatry, vol. 6, no. 5, pp. 183-187, 2007.

[13] L. Kase and D. R. Ledley, Anxiety Disorders: The Wiley Concise Guides to Mental Health, America, John Wiley and Sons, Inc, 2007, pp. 31-31.

[14] M. Badri, "Successes with Islamic counselling and psychotherapy," Presented at the National Seminar on Islamic Counselling, Kuala Lumpur, Islamic Center of Malaysia, 1995. 
[15] M. N. Omar, "Teknik merawat penyakit kemurungan dalam teori kaunseling Al-Kindi," (translated: Techniques in treating depression according to Al-Kindi Counselling Theory), (M874), presented at the International Seminar on Islamic Thoughts proceeding. Kuala Lumpur. International Islamic University, 7-9 December, 2004.

[16] Z. Kamal, Menuju Kesempurnaan Akhlak, (Translated: Towards attitude perfection by Helmi Hidayah), Bandung: Mizan, 1999.

[17] S. Khalili, S. Murken, A. Helmut, A. Shah, and A. Vahabzadeh, "Religious and mental health in cultural perspective: Observations and reflections after the first international congress on religion and mental health," The International Journal of Psychology of Religion, vol. 12, no. 4, pp. 217-237, 2002.

[18] D. R. William, D. B. Larson, R. E. Buckler, R. C. Heckmann, and C. M. Pyle, "Religion and psychological distress in a community sample," Social Sciences and Medicine. vol. 32, pp. 1257-1262, 1991.

[19] D. H. Rosmarin, K. I Pargament, and H. B. Robb, "Spiritual and religious issues in behavior change," Cognitive and Behavioral Practice, vol. 17, pp. 343-347, 2010.

[20] K. I. Pargament, "God help me: Toward a theoretical framework of coping for the psychology of religion," Research in the Social Scientific Study of Religion, vol. 2, pp. 195-224, 1990.

[21] S. E. Krauss, A. Hamzah, R. Juhari, and J. A. Hamid, "The Muslim religiosity-personality inventory (MRPI): Towards understanding differences in Islamic religiosity among Muslim youth," Pertanika Journal of Social Sciences and Humanity, vol. 13, no. 2, pp. 173-186, 2005.

[22] K. I. Pargament, The Psychology of Religion and Coping; Theory, Research, Practice, New York: Guilford, 1997.

[23] S. H. Lovibond and P. F. Lovibond, Manual for the Depression, Anxiety, Stress Scale, Sydney: psychology foundation, 1995.

[24] G. Edlira and L. Calderwood. (2001). English Longitudinal Studies of Ageing (ELSA) Socio-demographic characteristic. [Online]. Available: http://www.ifs.org.uk/elsa/report06/ch2.pdf

[25] C. Grady, M. Danis, K. L. Soeken, P. O’Donnell, C. Taylor, A. Farrar, and C. M. Ulrich, Does Education Influence Moral Action of Practicing Nurses and Social Workers? April 2008, vol. 8, no. 4, pp. 4-11.

[26] P. Allmark, "Can the study of ethics enhance nursing practice?" Journal of Advanced Nursing, vol. 51, no. 6, pp. 618-624, 2005.

[27] E. L. Csikai and M. Raymer, "Social workers' educational needs in end-of-life care," Social Work in Health Care, vol. 41, no. 1, pp. 53-72, 2005.

[28] L. T. Elo and S. H. Preston, "Educational differential in mortality: Unite states, 1979-1985," Social Sciences and Medicine, 1996, vol. 42, pp. 47-45.

[29] G. Pappas, S. Queen, W. Hadden, and G. Fisher, "The increasing disparity in mortality between socio-economic groups in the United States, 1960 and 1986," New England Journal of Medicine, vol. 329, pp. 103-109, 1993.

[30] M. Olff, W. Langeland, N. Draijer, and B. P. R. Gersons, "Gender differences in posttraumatic stress disorder," Psychological Bulletin, vol. 133, pp. 183-204, 2007.

[31] D. Oman and C. E. Thoresen, "Do religion and spirituality influence health?" in Handbook of the Psychology of Religion and Spirituality, R. F. Paloutzian and C. L. Park (Eds.), NY: Guilford, 2005, pp. 435-459.

[32] F. Rahman, "Some key ethical concepts of the Qur'an," The Journal of Religious Ethics, pp. 170-185, 2001.

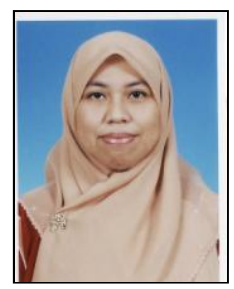

Husni Mohd Radzi is a postgraduate student from Universiti Sains Islam Malaysia (USIM) Selangor, Malaysia. In 2011, she was awarded with M.Ed in Guidance and Counseling from University Putra, Malaysia. She is currently pursuing her Ph.D. in Counseling in Universiti Sains Islam Malaysia, Negeri Sembilan Malaysia. She had several years experienced as student counselor and teaches counseling and Nasional, Selangor, Malaysia. psychology for undergraduates in Universiti Tenaga

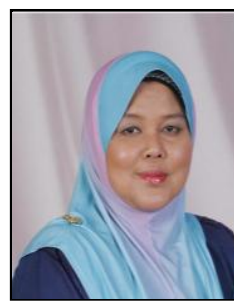

Sapora Sipon is an associate professor in the Faculty of Leadership and Management, USIM. As a licensed counsellor and psychologist, she is an active columnist in a local newspaper and participating in numerous research, paper presentations and conferences locally and internationally. She has published several books related to her field of counseling and psychology. She has won several innovation and invention awards in her years with USIM. She is currently the project leader for this research grant under Ministry of Education Malaysia.

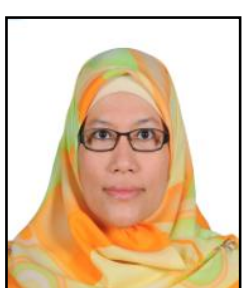

Education Malaysia.

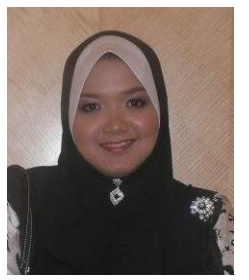

Nik Nadian Nisa Nik Nazli is a postgraduate student from Universiti Sains Islam Malaysia (USIM) Selangor, Malaysia. In 2010, she was awarded with master in information system management from University Technologay Mara Malaysia. She is currently pursuing her Ph.D. in human resource management in Universiti Sains Islam Malaysia, Negeri Sembilan Malaysia.

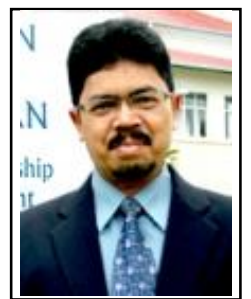

Zulkiple Abd Ghani is a professor in Islamic Dakwah, leadership and communication. $\mathrm{He}$ is currently a dean in the Faculty of Leadership and Management, USIM. He has published several books and numerous academics papers related to his field which he has presented in both international and local arena. He is also currently lead several researches under Ministry of Education Malaysia. 